\title{
Citizenship capability in gender perspective, activists, and specialization of science
}

\author{
M.M. Habibi*, Margono \& Sudirman \\ Universitas Negeri Malang, Malang, Indonesia \\ M.R.M. Rameli \\ Universiti Teknologi Malaysia, Johor, Malaysia
}

\begin{abstract}
This study aims to describe differences in citizenship capabilities in the perspective of gender, activists, and scientific specialization of students in East Java. The survey was conducted on 396 students from universities in East Java Indonesia who were drawn proportionally and randomly. Data was collected by questionnaire of citizenship capabilities on a scale of four. The three path ANOVA technique is used to analyze data. The results show that citizenship capabilities differ according to activists, but do not differ according to gender and scientific specialization. To improve citizenship capabilities, citizenship education is recommended so that it more equates students in the activities of campus organizations and the community.
\end{abstract}

Keywords: citizenship capabilities, gender activist, scientific specialization

\section{INTRODUCTION}

Citizenship capability is key in efforts to develop good citizens, namely citizens who can carry out obligations, and not just demand their rights. Citizens are required to be able to exercise their positive role in solving problems faced by their communities. Therefore, citizenship capabilities have a broad construct, not just the ability to act, but also include the ability to think critically and deep empathy towards people who are afflicted with problems. Chan's research (2012) shows that citizenship education that combines classroom activities and community activities can provide students with the experience to advocate for social justice.

Research on citizenship capabilities not only illustrates the construct of good citizenship in a democratic setting but also requires an understanding of the factors that contribute to the formation of these capabilities. The construct of citizenship capabilities developed by the Center for Civics Education (CCE) is limited to the ability to make action plans (Corporation for National Service, 2001). The construct is deemed inadequate because it has not provided a real experience in overcoming the problems of citizens. Costa Rica's experience in expanding the scope of citizenship capabilities shows the importance of the ability to cooperate with various parties in solving community problems (Fonseca \& Bujanda, 2011). In the Indonesian context, citizenship capabilities are ultimately realized in the ability to work together. The dimension of cooperation came from the agreement as a result of the deliberations they held. Of course, various abilities are needed so that citizens can conduct deliberations. This ability might include scientific and intellectual skills and attitudes toward citizenship.

Citizenship capability is a dependent variable that shows four citizens' abilities, namely the ability to start engaging in public deliberation, the ability to develop quality dialogue, the ability

*Corresponding Author 
to find thoughtful inquiry, and the ability to work together in solving problems in the community (Fonseca \& Bujanda, 2011).

The construction of citizenship capabilities is in line with the opinion of Birdwell, Scott, \& Horley (2013). Experience outside of school as a volunteer can improve student capabilities, especially those related to the relationship between work and the social environment. Capability can be defined as the power to do something. Class-based learning successfully notifies students. While service-learning is superior in developing citizenship capabilities, such as teamwork, the ability to hold on to tasks, empathy, keeping time, confidence, and getting along with people of various backgrounds. Service-learning is unique because of its impact on growing social awareness and awareness of citizens. Students feel more able to deal with community problems (efficacy). Increased participation makes students feel aware of the needs of the community, believes that they can make a difference, and is committed to serving the community in the present and later in life.

Urgent things to know are what factors determine the citizenship's capabilities. In the context of traditional Indonesian culture, gender is assumed to play a role in the formation of citizenship capabilities. The interesting thing is that universities living in the realm of modernity should not distinguish between men and women in the capabilities of their citizenship. In the tug of war between modernity and traditionality, gender and political relations in Indonesia become complex which involve cultural, ideological, and historical dimensions (Gadjah Mada University, 2009). This attraction is reflected in Sutarso's (2004) study. He concluded that gender issues in politics led to the rejection of the role of women in politics on the one hand, and support for women's political roles on the other. The problem is how the relationship between gender and citizenship capabilities.

Another factor is community social activities. It is suspected that the high level of community activity is positively related to citizenship capabilities. Research so far has only revolved around the relationship of student activity in school activities (curricular and extracurricular) and citizenship capabilities. Menezes's research (2003) shows that participation experience is generally obtained through student activities in sports and arts organizations, drama, music, or computer clubs. Students also participate in volunteer activities. Activities in schools related to citizenship are Scouts, religious organizations, and the environment. In general, such participation has a positive impact on the concept, attitude, and involvement of citizens. Participating students trust political institutions more, are interested in politics, like social movements in citizenship, and are more positive towards immigrants.

In the Indonesian context, history notes that the student movement reflects their responsibility towards more equitable sociopolitical change (Nugroho, 2013). It can be assumed that sociopolitical activity is positively related to increasing citizenship capabilities.

And the last factor that is thought to be related to citizenship capabilities is scientific specialization. There is no sufficient data that the study program taken by students influences citizenship capabilities. At the beginning of the Indonesian student movement, the activity of medical students in politics was very prominent. The national awakening began with the student political movement. In the colonial era, it was alleged that students with a background in natural sciences and engineering had high citizenship capabilities. Soekarno at that time was an engineering student. However, Hatta is an economics student and Soepomo is a law student. In the era of independence, the relationship between scientific specialization and citizenship capabilities has not been carefully studied.

\section{METHODS}

This research is classified as a type of survey research because researchers do not treat independent variables. The researcher tried to make a comparison between the citizenship capabilities between men and women; high, medium, and low organizational activities; and specification of scientific and social-humanities sciences.

This research was carried out with the following procedure. First, the researcher designs the construct of citizenship capabilities so that they are arranged sub-variables and indicators in the 
form of grid tables. Second, the researcher developed a citizenship capability questionnaire based on indicators that had been prepared previously. Third, the questionnaire was tested to analyze its validity and reliability. Fourth, a valid and reliable questionnaire is used to collect data on students of state and private universities in East Java. Fifth, the collected data is analyzed. Sixth, researchers write journal articles and research reports.

The research sample was determined by proportional random techniques and clusters. The sample was 396 students from four regional clusters in East Java, namely Jember, Malang, Surabaya, and Bangkalan. Each region is chosen by two universities (public and private). And each college is represented by two faculties (science and technology and social-humanities). The student population in all the areas studied amounted to 44,753 people. Calculation of sampling using the Solvin technique with a confidence level of $95 \%$ (Siregar, 2013).

The instrument of this research is a questionnaire about citizenship capabilities (AKK). The questions in this questionnaire were developed based on the variable construct of citizenship capabilities reflected in the grid. Each question in the AKK questionnaire has four answer choices that show the scale, namely one for the lowest and four for the highest. AKK questionnaire tested its validity with product-moment correlation analysis techniques. The question used in this study has a greater Pearson correlation value with a significance of 0.00 . Test reliability using the Cronbach alpha technique. AKK questionnaire was rated reliably with a reliability coefficient of 0.786 greater than 0.6 .

The research hypothesis is that the capabilities of the citizenship of East Java students differ according to gender, activists and their scientific backgrounds. Data analysis techniques to test the hypothesis are three-way ANOVA with SPSS version 23.

\section{RESULTS AND DISCUSSION}

\subsection{Gender perspective}

Of the total respondents as many as 396 as many as 166 respondents were male and as many as 230 respondents were female. The average citizenship capability for male students is 76.11 and women are 77.71. The sig value of Test of Between-Subjects Effects is 0.135 . With $\alpha=0.05$ it turns out $0.135>0.05$ so Ho is accepted. The decision is that there is no difference in citizenship capabilities based on gender.

The results of this study can be concluded that gender does not affect citizenship capabilities. This is different from the findings of Bilimoria, et al. (2010). He examines collaborative learning in class management by paying attention to gender aspects, and seeks to use classroom incidents related to gender diversity issues to eliminate discrimination. Gender is one of the problems that must be solved in citizenship education.

The equality of citizenship capabilities between men and women shows that women's representation in political institutions needs to be continuously improved. According to Sutarso's research (2011) the representation of women in people's representative institutions is always fewer, even though female voters are larger than male voters. If their citizenship capabilities are the same, it is necessary to pay attention to social, cultural and religious aspects in increasing women's participation (Arbaiyah, 2011).

\subsection{Activist perspective}

Student activities consist of their involvement in campus organizations, extra campus organizations, community organizations, and political parties. Students take part in campus organizational activities such as the Student Council, Student Representative Body, Student Senate, University Student Executive Board, Department Student Association, Faculty Student Executive Board, Student Activity Unit, and others. The extra-campus organizations attended by students were the Indonesian National Student Association, National Student Front, Indonesian National Student Movement, 
Indonesian Christian Student Movement, Islamic Student Association, Islamic Union Student Association (HIMA PERSIS), Indonesian Buddhist Student Association, Muhammadiyah Student Association, FL2MI, Unity Action of Indonesian Muslim Students, Campus Da'wah Institution, Indonesian Islamic Students, Indonesian Islamic Student Movement, Catholic Student Association of the Republic of Indonesia, Indonesian Muslim Student Union (SEMMI), and others. Community organizations include religious organizations, social organizations, hobby organizations, student organizations according to their fields of study, and others.

In the online questionnaire four questions were asked regarding activist variables, each question having the same weight value. Respondents who do not participate in the campus organizations will get a score of one while those who participate will get a value of two. This also applies to other questions related to activists, so the maximum value that students will get is eight, and the minimum value is four. The categorization of student activists is divided into five levels. Respondents who get the accumulated value of four are classified as very low, the respondents who get the accumulated value of five are classified as low, the respondents who get the accumulated value of six are classified as moderate, the respondents who get the accumulated value of seven are classified as high and the respondents who get the accumulated value eight are classified as very high.

Of the 396 respondents, 231 respondents classified as very low activity, as many as 99 respondents classified as low, as many as 28 respondents were moderate, as many as 33 respondents classified as high, and as many as 5 respondents classified as very high. The average citizenship capability for students with very low activity is 75.86 , low activity is 77.88 , moderate activity is 79.07 , high activity is 80.45 , and activity is very high is 81.20 . The sig value of the Test of BetweenSubjects Effects is 0.010 . Thus 0.010 is smaller than 0.05, so Ho is rejected. This means that there are differences in citizenship capabilities based on the high and low organizational activities that students follow.

The involvement of students in community organizations influences the improvement of citizenship capabilities. In the context of learning, it seems that citizenship is not enough to be taught in the classroom. Students must be immersed in a broader deliberation arena in the community, so that dialogue in the classroom is expanded with dialogue with community members, the government, and other stakeholders (Cooper, 2008; Fonseca \& Bujanda, 2011; Longo, 2013; Nishiyama, 2017). Active citizenship education research in the European Union based on collaborative action is focused on citizenship education carried out by non-governmental organizations (Directorate-General for Education and Culture, European Commission, 2007). Thus, research on mutual collaboration learning is needed which integrates citizenship education in schools and communities as a unit of social change movements.

Capability to participate significantly in social change is not limited to aspects of attitude and knowledge of citizenship. Citizenship capability that is far more important is the power to do things, such as teamwork, the ability to hold on to tasks, empathy, keep time, confidence, and get along with people of various backgrounds (Birdwell, et al. 2013).

According to Nishiyama (2017), children must be given a real experience to become real citizens. Children as actors in democracy are involved in the process of making decisions and solving problems with adults, for example in the form of children's congress forums, community planning, consultative forums, or youth-child parliaments. Children as agents of democracy have an effective role by increasing their contribution to the deliberative system. In other words, the deliberative system provides a space that allows children's unique involvement in democracy, even though their involvement does not significantly affect official government policies.

\subsection{Scientific specialization perspective}

Scientific specialization in this study is the scientific field taken by respondents in public and private universities which are the object of research that are grouped into 2 categories, namely social-humanities and science-technology. Students with science-technology specialties come from the faculties of engineering, Mathematics and Natural Sciences, medicine, and agriculture. And 
students with social-humanities specialties come from economic faculties, faculties of literature/culture, social/political sciences, and education/teacher science. A total of 202 respondents came from social-humanities specialties. And as many as 194 respondents came from sciencetechnology specialties. The average citizenship capability for social-humanities students is 77.86 . And the average citizenship capability of science-technology students is 76.20 . The sig value of Test of Between-Subjects Effects is 0.227 , far greater than $\alpha=0.05$. Ho is accepted, so there is no difference in citizenship capabilities based on scientific specialization.

The results of this study can be concluded that scientific specialization does not affect the capability of citizenship. This is in line with Oley's (2012) research which found that although social science faculty students have sufficient knowledge to participate in campus management, they are constrained by campus authorities who do not provide opportunities for their participation.

The results of this study are not in line with the findings of Putra's research (2012) regarding student activists from accounting backgrounds. He concluded that activist students had a social learning style, because of the busy life he had to be able to work with other students to complete his assignments, so he spent a lot of time on campus. Research Putra (2012) does not associate student activists with social and political activities, but provides an overview of social learning styles that are more directed at the ability to work together in citizenship capabilities.

\section{CONCLUSIONS}

Citizenship capabilities differ according to student activities in East Java, but do not differ according to gender and scientific specialization. Student activities in curricular and extracurricular campus organizations, community organizations, and political parties can improve citizenship capabilities. Thus, citizenship education must involve students in efforts to solve citizen problems through the synergy of campus organization activities and community organizations.

Since citizenship capabilities do not differ according to gender, women's political participation in representative institutions and other public organizations must be proportional. Social, cultural and religious barriers in implementing affirmative policies for women must be overcome.

The scientific specialization pursued by students does not affect the capability of citizenship. Thus, citizenship education which aims to enhance citizenship capabilities can use the same citizenship project model between science and social-humanities students.

\section{REFERENCES}

Arbaiyah, P. 2011. Politik perempuan indonesia. In Margono (Ed.). Pendidikan Pancasila: Topik aktual kenegaraan dan kebangsaan. Malang: Penerbit UM.

Birdwell, J. et al. 2013 Active citizenship, education and service learning. Education, Citizenship and Social Justice 8(2): 185-199.

Bilimoria, D. et al. 2010 Gender in the Management Education Classroom: A Collaborative Learning Journey. Journal of Management Education 34(6): 848-873.

Chan, C.K. 2012. Exploring an experiential learning project through Kolb's Learning Theory using a qualitative research method. European Journal of Engineering Education 37(4): 405-415.

Corporation for National Service. 2001. Active citizenship" in a facilitators guide to effective citizenship through americorps.

Directorate-General for Education and Culture, European Commission. 2007. Study on active citizenship education.

Fonseca, C. \& Bujanda M.E. 2011. Promoting children's capacities for active and deliberative citizenship with digital technologies: The CADE project in Costa Rica. ANNALS, AAPSS, 633: 243-262.

Gadjah Mada University. 2009. Workshop gender, politik, dan kekuasaan sekolah. Pascasarjana Universitas Gadjah Mada Yogyakarta.

Longo, N.V. 2013. Deliberative pedagogy in the community: Connecting deliberative dialogue, community engagement, and democratic education. Journal of Public Deliberation 9(2). 
Menezes, I. 2003. Participation experiences and civic concepts, attitudes and engagement: Implications for citizenship education projects. European Educational Research Journal 2(3): 430-445.

Nishiyama, K. 2017. Deliberators, not future citizens: Children in democracy. Journal of Public Deliberation 13(1): 56-68.

Nugroho, A. 2013. Peran dan fungsi mahasiswa. Retrieved from: http://catatanaktivismuda.blogspot.co.id/ 2013/08/peran-fungsi-mahasiswa-pfm.html. (Accessed on June 10, 2020).

Oley, P. C. (2012). Perilaku politik aktivis mahasiswa fakultas ilmu sosial dan ilmu politik universitas sam ratulangi (suatu studi terhadap pengurus organisasi mahasiswa Fakultas Ilmu Sosial dan Ilmu Politik Universitas Sam Ratulangi tahun 2012). Manado: Universitas Sam Ratulangi.

Putra, H.G.I. 2012. Perilaku belajar mahasiswa akuntansi: Aktivis, hedonis dan study oriented. (Unpublished thesis). Malang: Jurusan Akuntansi Universitas Brawijaya.

Siregar, S. 2013. Metode penelitian kuantitatif dilengkapii dengan perbandingan perhitungan manual \& spss. Jakarta: Kencana Prenada Media Group.

Sutarso, J. 2011. Konstruksi isu gender dalam politik: studi kasus pemilihan umum 2004. Komuniti 2(2): 1-13. 